Tropical Journal of Pharmaceutical Research April 2016; 15 (4): 773-779

ISSN: $1596-5996$ (print); 1596-9827 (electronic)

(C) Pharmacotherapy Group, Faculty of Pharmacy, University of Benin, Benin City, 300001 Nigeria.

All rights reserved.

Available online at http://www.tjpr.org

Original Research Article

http://dx.doi.org/10.4314/tjpr.v15i4.15

\title{
Indigofera tinctoria Linn (Fabaceae) attenuates cognitive and behavioral deficits in scopolamine-induced amnesic mice
}

\author{
Jong-Bo Kim, Spandana Rajendra Kopalli and Sushruta Koppula* \\ College of Biomedical and Health Sciences, Konkuk University, Chungju, Chungbuk Do, 380-701, Republic of Korea
}

*For correspondence: Email: sushrutak@gmail.com; Tel: 82-43-840-3609; Fax: 82-43-852-3616

Received: 9 November 2015

Revised accepted: 16 March 2016

\begin{abstract}
Purpose: To investigate the cognition-enhancing effects of aqueous extract of Indigofera tinctoria Linn (ITE, Fabaceae) in experimental amnesic mice.

Methods: Scopolamine (2 $\mathrm{mg} / \mathrm{kg}$, i.p.) was used to induce amnesia in mice. The cognitive-enhancing activity of the ITE (5, 10 and $20 \mu \mathrm{g} / \mathrm{mL}$ ) was studied by passive avoidance response, elevated plus maze and Y-maze behavioral paradigm in normal and scopolamine-induced amnesic mice. Antioxidant activities were also determined based on the ability of ITE to inhibit lipid peroxide, superoxide and hydroxyl radicals.

Results: Scopolamine-induced cognitive deficits were significantly reversed by ITE $(p<0.001$ at 20 $\mathrm{mg} / \mathrm{kg}$ ) in a dose-dependent fashion in all the behavioral paradigms tested. Furthermore, ITE dosedependently scavenged lipid peroxide, superoxide and hydroxyl free radicals with $50 \%$ inhibition concentration $\left(I C_{50}\right)$ of $7.28 \pm 0.37,5.25 \pm 0.28$ and $7.62 \pm 0.43 \mu \mathrm{g} / \mathrm{mL}$, respectively.

Conclusion: ITE possesses cognitive-enhancing properties in amnesic mice due to its potent antioxidant action.
\end{abstract}

Keywords: Indigofera tinctoria, Scopolamine, Lipid peroxidation, Amnesia, Antioxidant, Cognition

Tropical Journal of Pharmaceutical Research is indexed by Science Citation Index (SciSearch), Scopus, International Pharmaceutical Abstract, Chemical Abstracts, Embase, Index Copernicus, EBSCO, African Index Medicus, JournalSeek, Journal Citation Reports/Science Edition, Directory of Open Access Journals (DOAJ), African Journal Online, Bioline International, Open-J-Gate and Pharmacy Abstracts

\section{INTRODUCTION}

Cognition in a broad sense means the ability of the brain to encode, store and retrieve information [1]. The hippocampus contains the neural circuitry crucial for cognitive functions such as learning and memory, and intellectual aspects of mental functioning [2,3].Cognitive dysfunction, a major health problem in recent times can negatively affect learning and memory skills of individuals leading to the pathogenesis of various neurodegenerative disorders $[4,5]$. Mounting evidence suggests that oxidative damage in the central nervous system (CNS) is likely the cause of cognitive dysfunction. In particular, brain is believed to be vulnerable to oxidative stress due to a relatively high rate of oxygen free radical generation, with relatively reduced levels of antioxidative defenses [6,7].

Various antioxidant supplements and phytochemical components might be helpful for preserving brain functions and forestalling neurodegeneration [8]. Thus, agents that scavenge free radicals and regulate oxidative defense mechanisms may have potential in the mitigation of cognitive dysfunction seen in neurodegenerative disorders. Indigofera tinctoria Linn. (I. tinctoria, Fabaceae) a traditional medicinal herb has been widely used for several 
years in Indian and Chinese system of Medicine for the treatment of epilepsy, nervous disorders and liver ailments [9]. Experimental evidence suggests that $I$. tinctoria possesses anti-diabetic, anti-inflammatory, hepatoprotective, antiepileptic, anti-cancer and neuroprotective properties [9-11].

However, the cognitive-enhancing effect of $I$. tinctoria in amnesia conditions has not been studied. In the present study, we evaluated cognitive-enhancing effects of $l$. tinctoria extract in amnesia-induced experimental mice models. We also estimated the antioxidant defense potential of I. tinctoria extract.

\section{EXPERIMENTAL}

\section{Chemicals}

Scopolamine butyl bromide (SBB), 2 deoxy-Dribose, thiobarbituric acid, nitro blue tetrazolium (NBT) and riboflavin were purchased from Sigma Chemical Company, St. Louis, MO, USA. All other chemicals used were of analytical grade. Stock solutions of all chemicals were prepared in distilled water and the dilutions were made fresh on the day of the experiment.

\section{Plant material and preparation of $I$. tinctoria extract}

Dried aerial part of $I$. tinctoria was obtained from Chemiloids, Vijayawada, India in the month of August 2008. The plant material was authenticated by $\mathrm{Dr}$ Vidyadar KN, a taxonomist at VJ's College of Pharmacy and Research Institute, Rajahmundry, India and a voucher specimen (no. ITE-VJ/08) was deposited in Pharmacognosy Department Herbarium of the same institute. The plant material $(1 \mathrm{~kg})$ was powdered and extracted with boiling water $(5 \mathrm{~L})$ for 30 min using a Soxhlet apparatus. The filtrate was evaporated under vacuum at $<70{ }^{\circ} \mathrm{C}$ in a vacuum dryer to give a final yield of $74.12 \mathrm{~g}$. The extract was dissolved in sterile distilled water, filtered through a $0.22 \mu \mathrm{m}$ filter and stored at -20 ${ }^{\circ} \mathrm{C}$ until use.

\section{Animals}

Swiss albino mice of either sex weighing $20-25$ $\mathrm{g}$ were obtained from the animal house of National Institute of Nutrition, Hyderabad, India. The animals were housed in an air conditioned animal room at $23 \pm 2{ }^{\circ} \mathrm{C}$ with $12 / 12 \mathrm{~h}$ light/dark photoperiod, and given free access to food and water. The animals were kept for seven days in laboratory for habituation. All animal experiments were performed under the guidelines of Principles of Laboratory Animal Care $(\mathrm{NIH}$ publication no. 85-23, revised 1985) [12] and the Institutional Animal Care and Use Committee, Vishnu Institute of Pharmaceutical Education and Research, India (Reg no. 1358/ERe/S/10/ CPCSEA).

\section{Animal grouping and treatments}

The mice were divided into six groups $(n=15)$, i.e., vehicle, scopolamine (2 mg/kg), ITE (20 $\mathrm{mg} / \mathrm{kg}$ ), scopolamine plus ITE (5 $\mathrm{mg} / \mathrm{kg})$, scopolamine plus ITE $(10 \mathrm{mg} / \mathrm{kg})$ and scopolamine plus ITE $(20 \mathrm{mg} / \mathrm{kg})$. Different doses of ITE were prepared freshly by dissolving in distilled water and administered for 15 days through oral gavage. Scopolamine was prepared in normal saline. On the 15th day, after $60 \mathrm{~min}$ of administration of doses, acquisition trail for passive avoidance and the transfer latency for elevated plus maze was recorded. On the next day, 60 min after administration of ITE at various doses, amnesia was induced by administration of scopolamine $(2 \mathrm{mg} / \mathrm{kg}$, i.p.) and animals were tested for their memory tests $30 \mathrm{~min}$ after scopolamine administration. For Y-maze, animals received scopolamine $30 \mathrm{~min}$ before performing the test.

\section{Passive avoidance test}

Experimental sessions were conducted using GEMINI active and passive avoidance system (San Diego Instruments, San Diego, CA, USA) connected to a computer as described earlier [13]. The instrument has a bright and a dark compartment with a computer-controlled guillotine door between them. Each animal was familiarized with the behavioral apparatus for 2-3 $\min 24 \mathrm{~h}$ before the training session. The delivery of electric shocks, the raising and lowering of the door in the device were automatically controlled by the computer. On the day of training, animals were placed in dark compartment with heads facing the wall. After an acclimatization period of $30 \mathrm{~s}$ the guillotine door automatically opens and the animal was subjected to a trial of $270 \mathrm{~s}$. An entry into the dark compartment automatically shuts the door and the subject was punished with single low intensity foot shock of $0.5 \mathrm{~mA}$ for $5 \mathrm{~s}$. The latency period at which the animals stepped into the dark from the bright compartment were recorded by the computer. The transfer from one compartment to another was recorded as transfer latency time (TLT) in seconds. The first trial is for acquisition and retention is tested by a second trial after $24 \mathrm{~h}$. The shock is not delivered in the second trial. The criterion for learning was 
taken as an increase in the TLT on second trial (retention) relative to first trial (acquisition).

\section{Y-maze task}

Immediate working memory performance was assessed by recording spontaneous alternation behavior during a single session in a $\mathrm{Y}$-maze. Each arm was $40 \mathrm{~cm}$ long, $12 \mathrm{~cm}$ wide and 30 $\mathrm{cm}$ high. The procedure was similar as described previously [13]. Each mouse, naïve to the maze, was placed at the end of one arm and allowed to move freely through the maze during an $8 \mathrm{~m}$ session, and arm entries were counted. The series of arm entries was recorded visually by person blinded to treatment group and arm entry was considered to be completed when hind paws of the mouse were completely placed in the arm. Alternation was defined as successive entries into the three arms, on overlapping triplet sets. Alternation was calculated as the ratio of actual to possible alternation (defined as the total number of arm entries minus two), expressed a percentage.

\section{Elevated plus maze test}

The elevated plus maze serves as exteroceptive behavioral model for evaluating learning and memory in mice. The apparatus consists of two open arms $(16 \mathrm{~cm} \times 5 \mathrm{~cm})$ and two covered arms $(16 \mathrm{~cm} \times 5 \mathrm{~cm} \times 12 \mathrm{~cm})$. The arms extend from a central platform $(5 \mathrm{~cm} \times 5 \mathrm{~cm})$, and the maze is elevated to a height of $25 \mathrm{~cm}$ from the floor. On the first day, each animal was placed at the end of an open arm, facing away from the central platform. Transfer latency (TL) was taken as the time taken by an animal to move into one of the covered arms with all its four legs. TL was recorded on the first day. If the animal did not enter into one of the covered arms within $90 \mathrm{~s}$, it was gently pushed into one of the two covered arms, and TL was assigned as $90 \mathrm{~s}$. The animal was allowed to explore the maze for $10 \mathrm{~s}$ and was then returned to its home cage. Memory retention was examined $24 \mathrm{~h}$ after the first day trial [14].

\section{Lipid peroxidation inhibition assay}

Swiss albino mice of either sex weighing between $20-25 \mathrm{~g}$ were sacrificed by spinal traction. Whole brain were excised and washed in ice-cold Tris- $\mathrm{HCl}$ buffer $(0.1 \mathrm{M}, \mathrm{pH} 7.4)$, and cytosolic samples of liver and brain homogenate were prepared separately by using a tissue grinder (Thomas Scientific, NJ, USA) and centrifuging at $10,000 \mathrm{rpm}$ for $30 \mathrm{~min}$ at $4^{\circ} \mathrm{C}$. The thiobarbituric acid substance (TBARS) assay was performed as described previously [15]. The reaction mixture $(0.5 \mathrm{~mL})$ containing mice brain homogenate $(0.1 \mathrm{~mL}, 25 \% \mathrm{w} / \mathrm{v})$ in Tris- $\mathrm{HCl}$ buffer $(40 \mathrm{mM}, \mathrm{pH} 7.0), \mathrm{KCl}(30 \mathrm{mM})$, ferrous ion $(0.16 \mathrm{mM})$, and ascorbic acid $(0.06 \mathrm{mM})$ was incubated for $1 \mathrm{~h}$ at $37^{\circ} \mathrm{C}$ in the presence and absence of various dilutions of ITE $(1,5,10,15$ and $20 \mu \mathrm{g}$ ).

The incubation mixtures $(0.4 \mathrm{~mL})$ were treated with sodium dodecyl sulfate $(8.1 \%, 0.2 \mathrm{~mL})$, thiobarbituric acid $(0.8 \%, 1.5 \mathrm{~mL})$, and acetic acid $(20 \%, 1.5 \mathrm{~mL}, \mathrm{pH} 3.5)$. The total volume was then made up to $4 \mathrm{~mL}$ with distilled water and kept in a water bath at $100{ }^{\circ} \mathrm{C}$ for $1 \mathrm{~h}$. On cooling, $1 \mathrm{~mL}$ of distilled water and $5 \mathrm{~mL}$ of a mixture of $n$-butanol and pyridine $(15: 1 \mathrm{v} / \mathrm{v})$ were added and vortexed. After centrifugation, the absorbance of the organic layer was measured spectrophotometrically at $532 \mathrm{~nm}$ (model UV1601, Shimadzu). Inhibition of lipid peroxidation was determined by comparing the results of the test compound with those of the control, and expressed as a percentage. The $50 \%$ inhibition values were derived from a plot of ITE $(\mu \mathrm{g})$ against absorbance.

\section{Superoxide radical assay}

Superoxide scavenging activity of ITE was determined by the method described previously [15], which depends on light induced superoxide generation by riboflavin and the corresponding reduction of nitro blue tetrazolium (NBT). The assay mixture contained different concentrations of ITE $(1,5,10,15$ and $20 \mu \mathrm{g})$ and EDTA $(6 \mu \mathrm{M}$ containing $3 \mu \mathrm{g} \mathrm{NaCN})$, NBT $(50 \mu \mathrm{M})$, riboflavin $(2 \mu \mathrm{M})$ and phosphate buffer $(58 \mathrm{mM}, \mathrm{pH} 7.8)$ to give a total volume of $3 \mathrm{~mL}$. The tubes were uniformly illuminated for $15 \mathrm{~min}$ and thereafter the optical density (O.D) was measured at 560 nm using an UV Spectrophotometer (Shimadzu: UV- 1601). The $50 \%$ inhibition values were derived from a plot of ITE tested $(\mu \mathrm{g})$ against absorbance.

\section{Hydroxyl radical assay}

Hydroxyl radical scavenging activity was measured by studying the competition between deoxyribose and the extracts for hydroxyl radicals generated from the $\mathrm{Fe}^{3+} /$ ascorbate/EDTA $/ \mathrm{H}_{2} \mathrm{O}_{2}$ system (Fenton reaction). The hydroxyl radical attacks deoxyribose which eventually results in TBARS formation. Briefly, the reaction mixture contains deoxyribose $(2.8 \mathrm{mM})$, ferric chloride $(0.1 \mathrm{mM})$, EDTA (0.1 mM), $\mathrm{H}_{2} \mathrm{O}_{2}(1 \mathrm{mM})$, ascorbic acid $(0.1$ $\mathrm{mM})$, phosphate buffer $(20 \mathrm{mM}, \mathrm{pH} 7.4)$ and various dilutions of ITE $(1,5,10,15$ and $20 \mu \mathrm{g})$ in a final volume of $1 \mathrm{~mL}$. The reaction was 
incubated for $1 \mathrm{~h}$ at $37{ }^{\circ} \mathrm{C}$. Deoxyribose degradation was measured as TBARS by the method described earlier [15]. The $50 \%$ inhibition values were derived from a plot of ITE $(\mu g)$ against absorbance.

\section{Statistical analysis}

The results are expressed as mean \pm SEM. Statistical analysis was performed with SAS statistical software (SAS Institute, Cray, NC, USA) using one-way analysis of variance, followed by Dunnett's multiple range tests. $P<$ 0.05 was considered statistically significant.

\section{RESULTS}

\section{Effect of ITE on scopolamine-induced passive avoidance task in mice}

As shown in Fig. 1, TLT was significantly increased on the second trial $(221.5 \pm 16.9 \mathrm{~s})$ when compared with first trial $(15.9 \pm 1.3 \mathrm{~s})$ in control-trained group, but in scopolamine-treated group there was no significant increase on second trial $(17.05 \pm 3.01 \mathrm{~s})$ when compared with first trial $(18.21 \pm 3.4 \mathrm{~s})$. ITE treated alone group $(20 \mathrm{mg} / \mathrm{kg}$ ) did not influence the TLT and was similar to control group. Pre-treatment with different doses of ITE $(5,10$ and $20 \mathrm{mg} / \mathrm{kg})$ for 15 days increased the TLT on second trial (105.52 \pm $30.17 \mathrm{~s}$ for $5 \mathrm{mg} / \mathrm{kg}, 154.23 \pm 16.72 \mathrm{~s}$ for 10 $\mathrm{mg} / \mathrm{kg}$ and $185.46 \pm 22.62 \mathrm{~s}$ for $20 \mathrm{mg} / \mathrm{kg}$ ) when compared with first trial $(21.82 \pm 6.3 \mathrm{~s}, 20.2 \pm 3.3$ $\mathrm{s}$ and $23.81 \pm 11.51 \mathrm{~s}$ ), respectively in amnesic mice. The data indicate a dose-dependent effect, with $20 \mathrm{mg} / \mathrm{kg}$ showing the highest activity. There was no significant difference in TLT in the first trial among various groups.

\section{Effect of ITE on scopolamine-induced Y-maze task in mice}

As shown in Fig $2 \mathrm{~A}$, there was no significant difference observed in total arm entry of any group. However, administration of scopolamine $(2 \mathrm{mg} / \mathrm{kg}$, i.p) significantly $(p<0.001)$ decreased the percentage alternation (26.12 $\pm 1.35 \mathrm{~s})$ when tested 30 min after the administration in mice Fig 2B). Pre-treatment with ITE at indicated (5, 10 and $20 \mathrm{mg} / \mathrm{kg}$, p.o.) ameliorated the scopolamine-induced decreased percentage alternation in mice significantly $(p<0.05$ at 5 and $10 \mathrm{mg} / \mathrm{kg}$ and $p<0.01$ at $20 \mathrm{mg} / \mathrm{kg}$ ). Results indicated that ITE exhibited a dose dependent activity with $20 \mathrm{mg} / \mathrm{kg}$ exhibiting the highest effect (49. $42 \pm 0.95 \mathrm{~s})$.

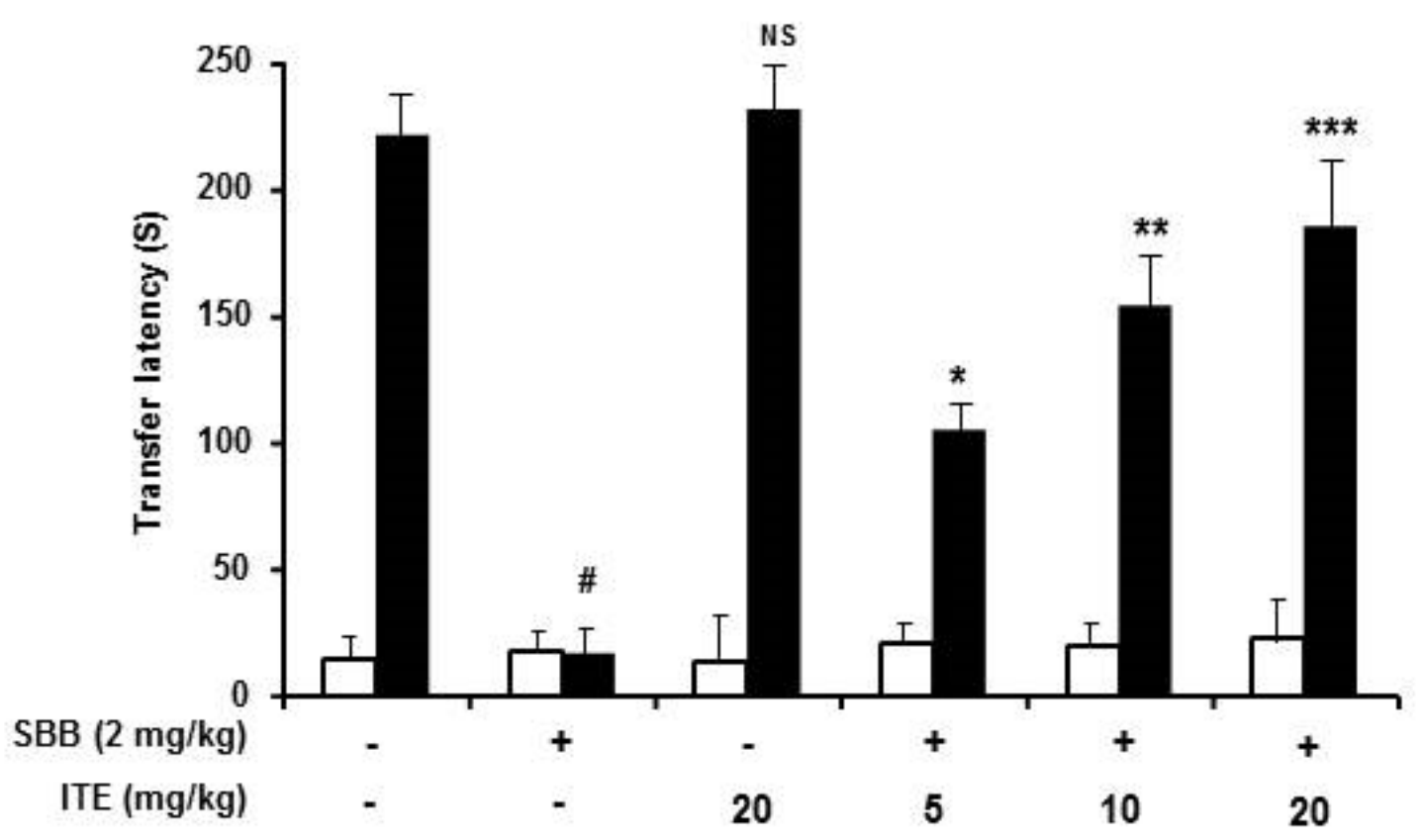

Figure 1: Effect of ITE on scopolamine-induced amnesia in passive avoidance test. Memory impairment was induced by scopolamine ( $2 \mathrm{mg} / \mathrm{kg}$, i.p.) $5 \mathrm{~min}$ before acquisition (Trial I), and retention (Trial II) was carried out 24 $\mathrm{h}$ after scopolamine treatment. $\square$ : Acquisition, $\mathbf{m}$ : Retention. ${ }^{\#} p<0.001$ compared with control group. NS: Not significant. ${ }^{*} p<0.05,{ }^{* *} p<0.01$ and ${ }^{* *} p<0.001$ compared with scopolamine group. Data is expressed as mean \pm S.E.M. $(n=5)$ using one-way ANOVA followed by Tuckey's Multiple comparison test in the Graph Pad Prism v5.01 software. SBB: Scopolamine butyl bromide; ITE: I. tinctoria aqueous extract 

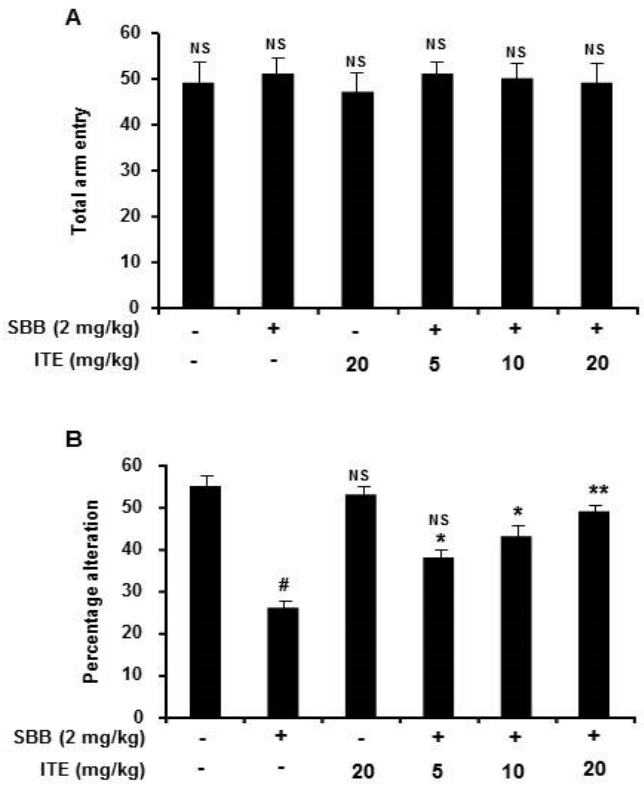

Figure 2: Effect of ITE on scopolamine-induced memory deficits in the Y-maze test. Spatial working memory was assessed using $\mathrm{Y}$ - Maze. Memory impairment was induced by scopolamine treatment $(2$ $\mathrm{mg} / \mathrm{kg}$, i.p.), and the test was carried out $30 \mathrm{~min}$ later. Total Arm entry $(A)$ and percentage alternation (B) was evaluated. ${ }^{\#} p<0.001$ compared with control group. NS: Not significant. ${ }^{*} p<0.05$ and ${ }^{* *} p<0.01$ compared with scopolamine group. Data is expressed as mean \pm SEM $(n=5)$ using one-way ANOVA followed by Tuckey's Multiple comparison test in the Graph Pad Prism v5.01 software. SBB: Scopolamine butyl bromide; ITE: I. tinctoria aqueous extract

\section{Effect of ITE on scopolamine-induced elevated plus maze test in mice}

The scopolamine treated group showed a significant increase $(p<0.05)$ in transfer latency values in the acquisition (153.12 $\pm 10.82 \mathrm{~s}$ ) as well as the retention period (127.64 $\pm 8.24 \mathrm{~s})$ over those of the vehicle control mice, indicating impairment in learning and memory (Fig. 3). Pretreatment with ITE at various doses (5, 10 and 20 $\mathrm{mg} / \mathrm{kg}$ ) for 15 days improved the memory in the elevated plus maze. ITE administration dosedependently $(p<0.5, p<0.01$ and $p<0.001$ at 5 , 10 and $20 \mathrm{mg} / \mathrm{mL}$ respectively), caused a significant reduction in the acquisition and retention latency in scopolamine-treated group with $20 \mathrm{mg} / \mathrm{mL}$ showing the highest effect (acquisition, $75.62 \pm 5.21 \mathrm{~s}$ and retention, 69.23 $\pm 4.21 \mathrm{~s})$.

\section{Effect of ITE on lipid peroxidation, superoxide and hydroxyl radical inhibition}

ITE at various concentrations (1, 5, 10 and 20 $\mu \mathrm{g}$ ) inhibited the lipid peroxide, superoxide and hydroxyl radicals in a dose-dependent manner (Fig. 4). The quantity of ITE $(\mu \mathrm{g})$ needed for 50 $\%$ inhibition was $7.28 \pm 0.3,7.62 \pm 0.4$ and 5.25 $\pm 0.4 \mu \mathrm{g} / \mathrm{mL}$, respectively (Fig $4 \mathrm{~A}-\mathrm{C}$ ).

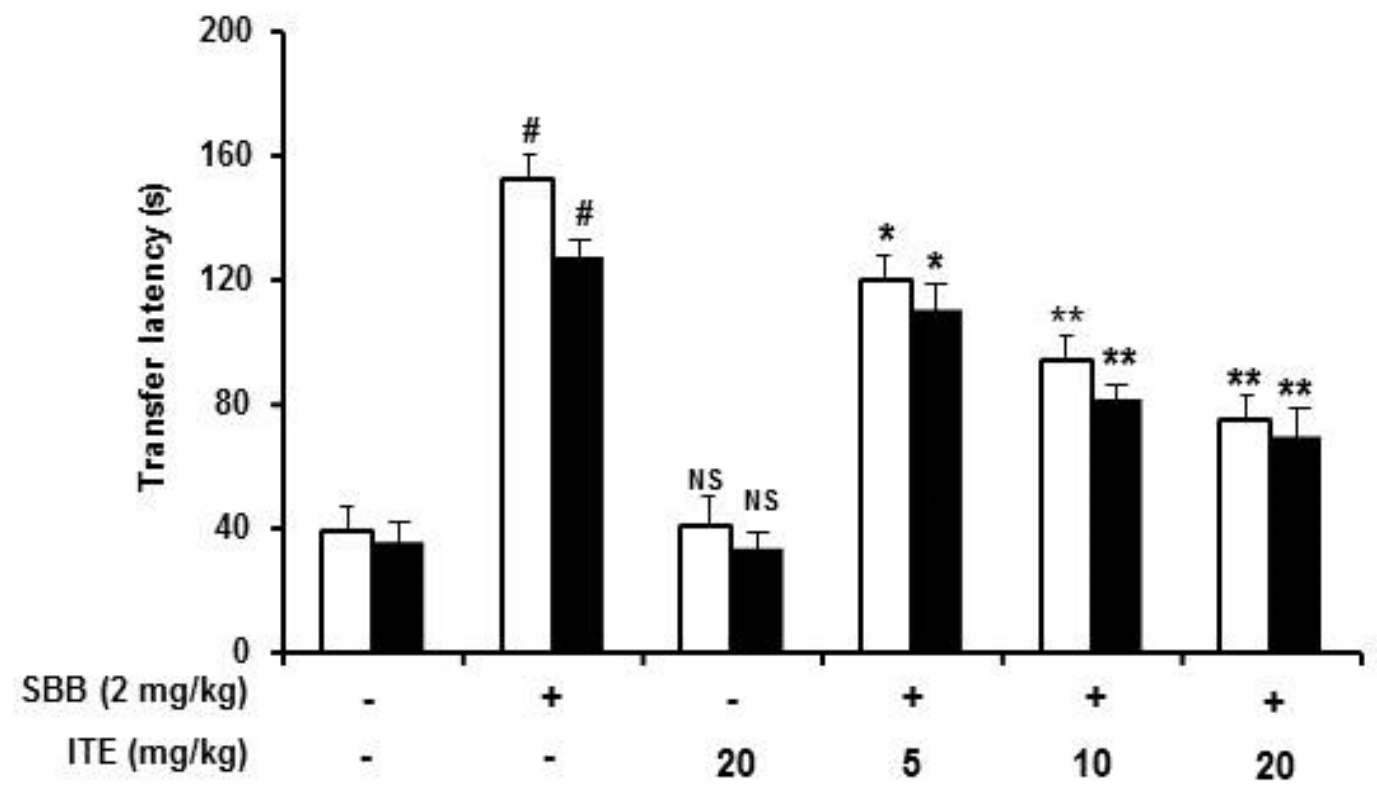

Figure 3: Effect of ITE on scopolamine-induced memory impairment in mice using the elevated plus maze test. Transfer latency in seconds was measured in first trial second trial. $\square$ : Acquisition, $\mathbf{m}$ : Retention. ${ }^{\#} p<0.001$ compared with control group. NS: Not significant. ${ }^{*} p<0.05$ and ${ }^{\star *} p<0.01$ compared with scopolamine group. Data is expressed as mean \pm S.E.M. $(n=5)$ using one-way ANOVA followed by Tuckey's Multiple comparison test in the Graph Pad Prism v5.01 software. SBB: Scopolamine butyl bromide; ITE: I. tinctoria aqueous extract 

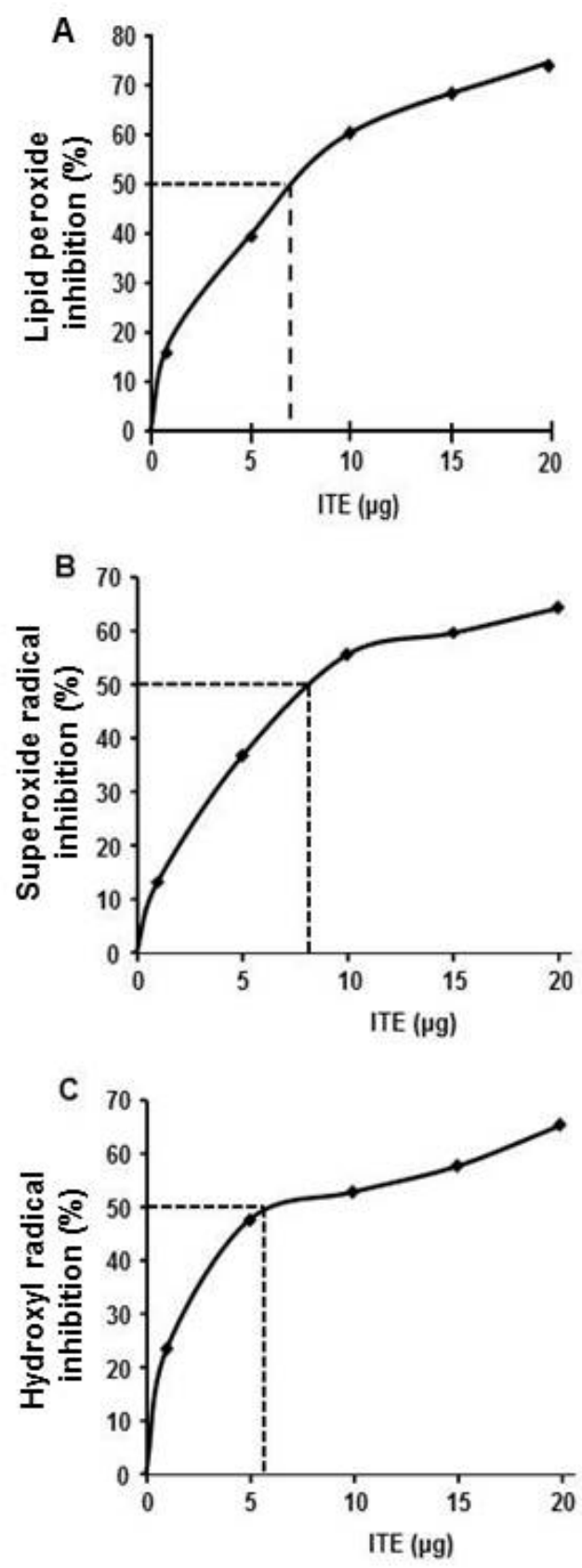

Figure 4: Effect of ITE on the inhibition of free radicals. A: Lipid peroxidation inhibition, B: Superoxide radical inhibition and $\mathrm{C}$ : Hydroxyl radical inhibition. $(n=6)$. The dotted lines indicate the concentration required for 50 percent inhibition. ITE: I. tinctoria aqueous extract

\section{DISCUSSION}

In the present investigation ITE showed significant inhibition of cognitive deficits observed in scopolamine-induced amnesic mice. Furthermore, the extract exhibited potent antioxidant action by inhibiting lipid peroxide, superoxide and hydroxyl radicals. Cognitive impairment is one of the major health problems and a characteristic symptom of several neurodegenerative disorders including Alzheimer's disease (AD) and Parkinson's disease (PD) [16]. Mounting evidence suggests that oxidative stress and free radicals might play a critical role in the process of cognitive impairments $[17,18]$. It is well documented that scopolamine induction impairs retrieval of memory in experimental animals and such amnesia is associated with a significant increase in oxidative stress [17]. Therefore, scopolamineinduced amnesia could be used as a valid model to study the role of antioxidant defense mechanisms in cognitive dysfunctions.

In the present study, the findings from passive avoidance test suggest that ITE at various doses (5, 10 and $20 \mathrm{mg} / \mathrm{kg}$ ) showed increase in TLT in retention trial of passive avoidance. Further, cognitive behavior evaluated through Y-maze test suggests an improvement in percentage alteration behavior in ITE treated groups against scopolamine-induced amnesia in a dosedependent manner. Furthermore, elevated plus maze test revealed that ITE showed protective effect in TL against scopolamine-induced amnesia dose-dependently. Moreover, the decrease in TL during retention period indicate the positive response of ITE in attenuating learning and memory deficits induced by scopolamine.

The major active constituents of $I$. tinctoria are the flavonoids, terpenoids, alkaloids, glycosides, methyl paraben, indigotine and indiruben [19]. Some of these constituents are well reported to possess antioxidant effects [20]. Further, it has been demonstrated that certain phenolic antioxidants form $I$. tinctoria attenuate neuronal cell death induced by oxidative stress in mouse PD models exhibiting neuroprotective properties based on antioxidant defense mechanisms $[9,18]$. In the present study, ITE scavenged the free radicals such as lipid peroxide, superoxide and hydroxyl radical indicating their usefulness in oxidative stress-related cognitive dysfunctions. Importantly, ITE scavenged the lipid peroxides in a concentration-dependent manner in brain homogenates of mice indicating that ITE might play a major role in mitigating CNS oxidative stress.

\section{CONCLUSION}

This study provides scientific support for the use of ITE in alleviating cognitive deficits induced by scopolamine in mice which might be due to its antioxidant action. Based on these present results and some traditional medicinal claims, ITE may be developed as a potential therapeutic 
agent in attenuating cognitive dysfunctions seen in aging and neurodegenerative diseases.

\section{ACKNOWLEDGEMENT}

This work was supported by Konkuk University.

\section{REFERENCES}

1. Martin SJ, Grimwood PD, Morris RG. Synaptic plasticity and memory: an evaluation of the hypothesis. Annu Rev Neurosci 2000; 23: 649-711.

2. Trivedi JK. Cognitive deficits in psychiatric disorders: current status. Indian J Psychiat 2006; 48: 10-20.

3. Ingole SR, Satynaran K, Rajput Sharma SS. Cognition enhancer: current strategies and future perspectives. CRIPS 2008; 9: 42-48.

4. Kim JJ, Diamond DM. The stressed hippocampus, synaptic plasticity and lost memories. Nat Rev Neurosci 2002; 3: 453-462.

5. Sandi $C$. Stress cognitive impairment and cell adhesion molecules. Nat Rev Neurosci 2004; 5: 917-930.

6. Brewer GJ. Age-related toxicity to lactate, glutamate, and $b$-amyloid in cultured adult neurons. Neurobiol Aging 1998; 19: 561-568.

7. Sohal RS, Arnold LA, Sohal BH. Age-related changes in antioxidant enzymes and prooxidants generation in tissues of the rat with special reference to parameters in two insect species. Free Radic Biol Med 1990; 10: 495 500.

8. Papandreou MA, Tsachaki $M$, Efthimiopoulos $S$, Cordopatis $P$, Lamari FN, Margarity M. Memory enhancing effects of saffron in aged mice is correlated with antioxidant protection. Behav Brain Res 2011; 219 . 197-204.

9. RajendraKopalli $S$, Koppula S, Shin $K Y$, Noh SJ, Jin Q, Hwang BY, Suh YH. SF-6 attenuates 6hydroxydopamine-induced neurotoxicity: an in vitro and in vivo investigation in experimental models of Parkinson's disease. J Ethnopharmacol 2012; 143(2): 686-694.

10. Tyagi PK, Rai VK, Pahria AK, Kumar SS, Singh Y, Sharma M, Goval M. Preliminary phytochemical screening and evaluation of antiinflammatory activity of ethanolic extract of leaves of Indigofera tinctoria Linn. $J$ Curr Pharm Res 2010; 3: 47-50.

11. Asuntha G, Prasannaraju Y, Prasad KVSRG. Effect of ethanol extract of Indigofera tinctoria Linn. (Fabaceae) on lithium/pilocarpine-induced status epilepticus and oxidative stress in Wistar rats.Trop J Pharm Res 2010; 9: 149-156.

12. Derrell C. "Guide for the care and use of laboratory animals. Institute of laboratory animal resources. National Academy Press, Washington DC, USA 1996.

13. Kumar H, Kim BW, Song SY, Kim JS, Kim IS, Kwon YS, Koppula S, Choi DK. Cognitive enhancing effects of alpha asarone in amnesic mice by influencing cholinergic and antioxidant defense mechanisms. Biosci Biotechnol Biochem 2012; 76(8): 1518-1522.

14. Kasture SB, Kasture VS, Joshua AJ. Damodaran A, Amit A. Nootropic activity of BacoMind ${ }^{T M}$, an enriched phytochemical composition from Bacopamonnieri. J Nat Rem 2007; 7: 166-173.

15. Satyanarayana S, Sushruta K, Sarma GS, Srinivas N, Subba-Raju GV. Antioxidant activity of the aqueous extracts of spicy food additives--evaluation and comparison with ascorbic acid in in-vitro systems. J Herb Pharmacother 2004; 4(2): 1-10.

16. Vasudevan M, Milind P. Memory-enhancing activity of Thespesiapopulnea in rats. Pharm Biol 2007; 45: $267-$ 73.

17. El-Sherbiny DA, Khalifa AE, Attia AS, Eldenshery ED. Hypericum perforatum extract demonstrates antioxidant properties against elevated rat brain oxidative status induced by amnestic dose of scopolamine. Pharmacol Biochem Behav 2003; 76: 525-533.

18. Mountjoy CQ, Rossor $M N$, Iversen $L L$, Roth $M$. Correlation of cortical cholinergic and GABA deficits with quantitative neuropathological findings in senile dementia. Brain 1984; 107(2): 507-518.

19. Motamarri SN, Karthikeyan M, Rajasekar S, Gopal V. Indigofera tinctoria Linn - A phytopharmacological review. Int J Res Pharm Biomed Sci 2012; 3: 164-169.

20. Kopalli SR, Noh SJ, Koppula S, Suh YH. Methylparaben protects 6-hydroxydopamine-induced neurotoxicity in SH-SY5Y cells and improved behavioral impairments in mouse model of Parkinson's disease. Neurotoxicol 2013; 34: 25-32. 